OPEN ACCESS

Edited by:

József Tímár,

Semmelweis University, Hungary

${ }^{*}$ Correspondence:

Jiaolin Zhou

conniezhj/@163.com

Guole Lin

linguole@126.com

tORCID:

Yang An

orcid.org/0000-0002-0629-9440

Jiaolin Zhou

orcid.org/0000-0003-2020-5161

Guole Lin

orcid.org/0000-0001-6225-3028

Huanwen Wu

orcid.org/0000-0002-3996-3176

Lin Cong

orcid.org/0000-0002-9222-8859

Xiaoyuan Qiu

orcid.org/0000-0003-1494-9068

Weikun Shi

orcid.org/0000-0003-4813-2419

Received: 28 April 2021 Accepted: 14 July 2021

Published: 26 July 2021

Citation:

An $Y$, Zhou J, Lin G, Wu H, Cong L,

Li Y, Qiu X and Shi W (2021)

Clinicopathological and Molecular

Characteristics of Colorectal Signet

Ring Cell Carcinoma: A Review.

Pathol. Oncol. Res. 27:1609859.

doi: 10.3389/pore.2021.1609859

\section{Clinicopathological and Molecular Characteristics of Colorectal Signet Ring Cell Carcinoma: A Review}

\author{
Yang $\mathrm{An}^{1 \dagger}$, Jiaolin Zhou ${ }^{1 * \dagger}$, Guole $\mathrm{Lin}^{1 * t}$, Huanwen $\mathrm{Wu}^{2 \dagger}$, Lin Cong ${ }^{1 \dagger}$, Yunhao $\mathrm{Li}^{1 \dagger}$, \\ Xiaoyuan Qiu ${ }^{1+}$ and Weikun Shi ${ }^{1+}$
}

${ }^{1}$ Department of General Surgery, Peking Union Medical College Hospital, Chinese Academy of Medical Sciences and Peking Union Medical College, Beijing, China, ${ }^{2}$ Department of Pathology, Peking Union Medical College Hospital, Chinese Academy of Medical Sciences and Peking Union Medical College, Beijing, China

Colorectal signet ring cell carcinoma (SRCC) is a rare subtype of colorectal cancer (CRC) with unique characteristics. Due to the limited researches on it, a comprehensive and indepth understanding of this subtype is still lacking. In this article, we summarize the clinicopathological features and molecular characteristics of colorectal SRCC based on a literature review. Clinically, SRCC has been associated with young age, proximal site preference, advanced tumor stage, high histological grade, high rate of lymph node involvement, frequent peritoneal metastasis, and a significantly poor prognosis. Regarding molecular characteristics, in SRCC, the mutation burden of the classic signaling pathways that include WNT//-catenin, RAS/RAF/MAPK, and PI3K/AKT/mTOR signaling pathways are generally reduced. In contrast, some genes related to the "epithelial-mesenchymal transition (EMT) process" and the "stem cell properties", including RNF43, CDH1, and $S M A D 4$, as well as the related TGF- $\beta$ signaling pathway have been observed more frequently altered in SRCC than in conventional adenocarcinoma (AC). In many studies but not in others, SRCC showed a higher frequency of BRAF mutation, microsatellite instability-high (MSI-H) and $\mathrm{CpG}$ island methylator phenotype (CIMP) positive status compared to $\mathrm{AC}$. It has been proposed that colorectal SRCC consists of two subtypes, in which the $\mathrm{MSI}^{+} / \mathrm{CIMP}^{+} / B R A F^{+} / \mathrm{CD} 3^{+} / \mathrm{PD}-\mathrm{L}^{+}{ }^{+}$hypermethylated genotype is more common in the proximal colon, and may represent the potential candidate for immunotherapy. Understanding the special molecular mechanisms related to the aggressive biology of SRCC is of great importance, which may provide a theoretical basis for the development of more targeted and effective treatments for this refractory disease.

Keywords: colorectal cancer, clinicopathology, signet ring cell carcinoma, molecular features, review

\section{INTRODUCTION}

Colorectal cancer (CRC) ranks the third most common cancer and the second leading cause of cancer-related death globally [1,2]. First proposed by Saphir and Laufman in 1951 [3], signet ring cell carcinoma (SRCC) is a rare subtype of CRC, by definition composed of at least $50 \%$ of neoplastic cells showing signet ring cell (SRC) morphology. Among all subtypes of CRC, the conventional adenocarcinoma (AC) accounts for the vast majority, the mucinous adenocarcinoma (MAC) 
accounts for $10-15 \%$, and SRCC only accounts for $~ 1 \%$ [4-8]. During the past 3 decades, epidemiology data of the United States showed an overall decline in the incidence of CRC, while a rising trend has been observed for young adult patients [9-11]. Several studies have shown a more aggressive manifestation for the earlyonset CRC and an increased incidence of SRC histology $[9,12]$. Because of the rarity of colorectal SRCC, many aspects of it have not been fully elucidated. In this article, we describe and discuss the clinicopathological features and molecular characteristics of colorectal SRCC based on a literature review. We searched MEDLINE and PreMEDLINE database for English-language articles and references from relevant articles. Search terms included "signet ring cell", "colorectal", "colon", "rectum", "carcinoma", "cancer", "epidemiology", "clinicopathological", "molecular", "genotype", "mutation", "microsatellite instability", "BRAF", "prognosis", "survival", "metastasis", "surgery", "chemotherapy", and "treatment". We summarized the results of studies that analyzed the clinicopathological and/or molecular characteristics of colorectal SRCC based on population-based registries, single-center or multi-center cohorts, published between January 1999 and January 2021. Studies that did not distinguish mucinous adenocarcinoma from SRCC were ruled out. Articles solely reported in the form of abstracts or meeting reports are excluded.

\section{CLINICOPATHOLOGICAL FEATURES OF COLORECTAL SIGNET RING CELL CARCINOMA}

Being a kind of poorly cohesive carcinoma [13], colorectal SRCC is a distinct entity with different clinical manifestations, pathological features, and biological behaviors compared to AC. Studies upon the clinicopathological features of colorectal SRCC were summarized in Table 1 and Figure 1.

\section{PATIENT DEMOGRAPHICS}

SRCC are reported to be diagnosed at younger age compared to AC [5,6,9,14-16]. The age limit defining early-onset CRC varies from studies to studies, while under 40 years of age has been adopted by most authors [9,12,17-20]. Population-based studies using the surveillance, epidemiology, and end results (SEER) program cancer registry revealed a mean age at onset of about 65 years old for colorectal SRCC (Table 1), which is 3.5 years earlier than that of AC [7]. Although overall CRC is more common in men than in women, while according to largescale studies, the incidence of colorectal SRCC in both sexes is roughly equal $[5-7,21]$.

\section{CLINICAL CHARACTERISTICS}

Clinically, colorectal SRCC has some different characteristics from AC. Patients often have larger tumors and more advanced tumor stages at initial diagnosis $[5,9,22]$. Unlike the
AC morphology of intraluminal mass, colorectal SRCC often appears as diffuse circumferential thickening of the bowel wall with markedly narrowed lumen, and sometimes presents similar to inflammatory disease [17,23]. Psathakis and others [24] analyzed patients' primary symptoms at diagnosis and suggested that the frequently advanced stages may result from a delay in diagnosis, which may be attributed to the special features of colorectal SRCC including younger age at onset, atypical and delayed clinical manifestations, and the high false-negative rates of endoscopic biopsy [17,23]. Psathakis proposed that the characteristic long-term intramural tumor growth without penetrating the mucosa might be one explanation for the special features of SRCC [24].

\section{DISTRIBUTION OF SITES}

It has been suggested that right- and left-sided CRC may arise by different mechanisms $[25,26]$. Although with some exceptions in reports of Asian population [27,28], most large-scale studies from western countries revealed a proximal colon (including the cecum, ascending and transverse colon) dominance for colorectal SRCC $[5,6,14,16,29,30]$. Overall, rectal cancer accounts for nearly $30 \%$ of all CRC [5,6,16,21,31]. In contrast, SRCC of the rectum is less common and accounts for $\sim 20 \%$ of all colorectal SRCC $[5,6,16,30]$. The embryological and genetic differences between the proximal colon that originates from the midgut, and the distal colon and rectum from the hindgut might partly explain the peculiarity of SRCC distribution.

\section{AGGRESSIVE BEHAVIOR}

Colorectal SRCC has been identified as a subtype with aggressive biological behavior. In comparison with AC, SRCC usually has higher tumor grade and is diagnosed in more advanced stage $[6,8,9,14,16,29]$ (Table 1). In addition, adverse histological features including higher percentage of locoregional lymph node involvement, lympho-vascular invasion and perineural infiltration are more common in colorectal SRCC [8,9,14,18,27] (Table 1).

Compared to AC patients, SRCC patients more frequently have local and distant metastasis and are more likely to have multiple-site tumor spread, which is characterized by a significantly higher incidence of peritoneal dissemination (more than $50 \%$, as reported by the large-scale autopsy study of Hugen et al. [32]) and distant lymph node metastasis, and a lower incidence of hepatic and lung metastasis. In addition, SRCC patients show divergent metastatic pattern with involvement of rare metastatic sites including bone, brain, bone marrow, ovaries, skin, heart, and can present as multiple polypoid colonic lesions $[8,14,15,32-34]$. The underlying mechanism for this distinct metastatic pattern is unclear. Histologically, SRCs are usually present as single cells or in loose clusters. Some authors suggested that this may imply a lack of cell-cell adhesion, that is, the SRCs can loosen contact with surrounding structures, causing them to 
TABLE 1 | Clinicopathological features of colorectal signet ring cell carcinoma

\begin{tabular}{|c|c|c|c|c|c|c|c|c|c|c|c|c|c|c|c|c|c|c|c|c|c|}
\hline \multirow[t]{2}{*}{ Study } & \multirow[t]{2}{*}{ Year } & \multirow{2}{*}{$\begin{array}{l}\text { Study } \\
\text { type }\end{array}$} & \multirow{2}{*}{$\begin{array}{c}\text { No. } \\
\text { of } \\
\text { SRCC } \\
(\%)\end{array}$} & \multirow[t]{2}{*}{ Age (years) } & \multirow{2}{*}{$\begin{array}{c}\text { Gender } \\
\mathrm{M} / \mathrm{F}\end{array}$} & \multicolumn{3}{|c|}{ Location (\%) } & \multirow{2}{*}{$\begin{array}{l}\text { High } \\
\text { grade } \\
\text { (G/4/4) }\end{array}$} & \multirow{2}{*}{$\begin{array}{l}\text { TNM } \\
\text { stage } \\
\text { III-IV }\end{array}$} & \multirow{2}{*}{$\begin{array}{c}\text { Stage } \\
\mathbf{N}+ \\
(\mathbf{L N} \\
\text { positive) } \\
(\%)\end{array}$} & \multirow{2}{*}{$\begin{array}{l}\text { Angio- } \\
\text { invasion }\end{array}$} & \multicolumn{7}{|c|}{ Site of metastasis (\%) } & \multicolumn{2}{|c|}{ Prognosis } \\
\hline & & & & & & $\begin{array}{l}\text { Proximal } \\
\text { colon }\end{array}$ & $\begin{array}{l}\text { Distal } \\
\text { colon }\end{array}$ & Rectum & & & & & Peritoneum & Ovary & Liver & Lung & Bone & $\begin{array}{l}\text { Distant } \\
\text { LN }\end{array}$ & Others & $\begin{array}{l}\text { Survival } \\
\text { rate } \\
(\%)\end{array}$ & $\begin{array}{l}\begin{array}{c}\text { Survival } \\
\text { (months) }\end{array} \\
\end{array}$ \\
\hline $\begin{array}{l}\text { Psathakis, } \\
1999[24]\end{array}$ & 1979-1997 & $\begin{array}{l}\text { Retro. Single-center } \\
\text { (Germany) }\end{array}$ & $\begin{array}{c}14 \\
(0.88 \%)\end{array}$ & $67.5 \pm 16.9$ & $1.0: 1$ & $50.0 \%$ & $28.6 \%$ & $21.4 \%$ & - & $92.9 \%$ & - & - & $64.3 \%$ & $7.1 \%$ & $14.3 \%$ & 0 & 0 & - & $14.3 \%$ & $\begin{array}{l}\text { 3-year } \\
\text { OS, } 0.0 \%\end{array}$ & $\begin{array}{l}\text { Median OS, } \\
14 \mathrm{~ms}\end{array}$ \\
\hline $\begin{array}{l}{ }^{\text {TKang, }} \\
2005[16]\end{array}$ & $1991-2000$ & Review of SEER data & $\begin{array}{l}1,522 \\
(0.9 \%)\end{array}$ & $65.9 \pm 16.6$ & $1.0: 1$ & $60.0 \%$ & $18.6 \%$ & $21.4 \%$ & $73.5 \%$ & $80.9 \%$ & - & - & - & - & - & - & - & - & - & $\begin{array}{l}5-\mathrm{yS} \\
26.8 \%\end{array}$ & - \\
\hline $\begin{array}{l}\text { Sung, } \\
2008[27]\end{array}$ & 1995-2006 & $\begin{array}{l}\text { Retro. Single-center } \\
\text { (Korea) }\end{array}$ & 65 (NA) & $50.8 \pm 17.2$ & $1.7: 1$ & $35 \%$ & $65 \%$ lle & t-sided) & - & $89 \%$ & $\begin{array}{l}\mathrm{pN}+, 88 \% \\
\mathrm{pN} 2,77 \%\end{array}$ & $89 \%$ & - & - & - & - & - & - & - & $\begin{array}{l}\text { 3-year } \\
\text { Cumulative } \\
\text { OS. } 33 \%\end{array}$ & $\begin{array}{l}\text { Mean OS, } \\
48.4 \mathrm{~ms}\end{array}$ \\
\hline $\begin{array}{l}\text { Chew, } \\
2010[90]\end{array}$ & 1999-2005 & $\begin{array}{l}\text { Retro. Single-center } \\
\text { (Singapore) }\end{array}$ & $\begin{array}{c}30 \\
(1.1 \%)\end{array}$ & 63.5 (median) & $0.4: 1$ & $27 \%$ & $46 \%$ & $27 \%$ & $77 \%$ & $94 \%$ & $89 \%$ & - & $50 \%$ & & $7 \%$ & $22 \%$ & - & - & - & $\begin{array}{l}\text { 5-year } \\
\text { cSs, 11.1\% }\end{array}$ & - \\
\hline $\begin{array}{l}\text { Mizushima, } \\
2010 \text { [38] }\end{array}$ & 1993-2007 & $\begin{array}{l}\text { Review of Osaka } \\
\text { databasese (Japan) }\end{array}$ & $\begin{array}{c}19 \\
(0.32 \%)\end{array}$ & $65.5 \pm 10.9$ & $0.7: 1$ & $55.6 \%$ & $5.6 \%$ & $38.9 \%$ & - & - & $\begin{array}{l}\mathrm{pN}+73.7 \% ; \\
\mathrm{pN2}, 47.4 \%\end{array}$ & - & $31.6 \%$ & - & $10.5 \%$ & 0 & 0 & $5.3 \%$ & - & $\begin{array}{l}5 \text {-year } \\
\text { OS, 24.1\% }\end{array}$ & $\begin{array}{l}\text { Median OS, } \\
15 \mathrm{~ms}\end{array}$ \\
\hline $\begin{array}{l}\text { Hyngstrom, } \\
2012[6]\end{array}$ & 1998-2002 & $\begin{array}{l}\text { Review of NCDB } \\
\text { data }\end{array}$ & $\begin{array}{l}2,260 \\
(1 \%)\end{array}$ & $\begin{array}{l}18-49 \text { years, } 19 \% ; \\
50-75 \text { years, } 51 \% ; \\
76-90 \text { years, } 29 \%\end{array}$ & $1.0: 1$ & $62 \%$ & $19 \%$ & $20 \%$ & $77 \%$ & $80 \%$ & - & - & - & - & - & - & - & - & - & - & - \\
\hline $\begin{array}{l}\text { Kakar, } \\
2012 \text { [28] }\end{array}$ & & $\begin{array}{l}\text { Retro. Multi-center } \\
\text { (United States) }\end{array}$ & $33(\mathrm{NA})$ & 56.4 (mean) & $2.7: 1$ & $48 \%$ & 52\% lle & t-sided) & - & $79 \%$ & - & - & - & - & - & - & - & - & - & - & - \\
\hline $\begin{array}{l}\text { Nitsche, } \\
2013[8]\end{array}$ & 1982-2012 & $\begin{array}{l}\text { Retro. Single-center } \\
\text { (Germany) }\end{array}$ & $\begin{array}{c}30 \\
(0.9 \%)\end{array}$ & 64 (median) & $1.7: 1$ & $50 \%$ & $13 \%$ & $37 \%$ & $90 \%$ & $87 \%$ & $\begin{array}{l}\mathrm{pN}+, 83 \% \\
\mathrm{pN} 2,73 \%\end{array}$ & $17 \%$ & - & - & - & - & - & - & - & $\begin{array}{l}5 \text {-years CSS, } \\
21 \pm 8 \%\end{array}$ & $\begin{array}{l}\text { Median CSS, } \\
10 \mathrm{~ms}\end{array}$ \\
\hline $\begin{array}{l}\text { Thota, } \\
2014 \text { [29] }\end{array}$ & 1995-2009 & $\begin{array}{l}\text { Review of VACCR } \\
\text { data }\end{array}$ & $\begin{array}{l}206 \\
206 \\
(0.6 \%)\end{array}$ & 67 (median) & 33.3:1* & $75.6 \%$ & $24.4 \%$ & NA & $85.5 \%$ & $78.8 \%$ & $\begin{array}{l}\mathrm{pNN}, 69.1 \% \\
\mathrm{pN} 2,4.6 \%\end{array}$ & - & - & - & - & - & - & - & - & $\begin{array}{l}5 \text {-years OS of } \\
\text { Stage III, 19\% }\end{array}$ & $\begin{array}{l}\text { Median OS, } \\
18.6 \mathrm{~ms}\end{array}$ \\
\hline $\begin{array}{l}\text { Hugen, } \\
2015[\text { []] }\end{array}$ & 1989-2010 & $\begin{array}{l}\text { Review of NCR data } \\
\text { (Dutch) }\end{array}$ & $\begin{array}{l}1,972 \\
(1 \%)\end{array}$ & 70 (median) & $1.0: 1$ & $59.7 \%$ & $22.3 \%$ & $18.0 \%$ & - & $78.0 \%$ & - & - & - & - & - & - & - & - & - & $\begin{array}{l}\text { Colon: 5-y } \\
\text { RS, 30.8\% } \\
\text { Rectum: } 5-y \\
\text { RS, } 19.5 \%\end{array}$ & - \\
\hline $\begin{array}{l}\text { Nitsche, } \\
2016[14]\end{array}$ & 1998-2012 & $\begin{array}{l}\text { Review of Munich } \\
\text { Cancer Registry } \\
\text { (Germany) }\end{array}$ & $\begin{array}{c}160 \\
(0.6 \%)\end{array}$ & $66 \pm 15$ & $1.2: 1$ & $77.8 \%$ & $9.2 \%$ & $13.1 \%$ & $96.2 \%$ & $85.7 \%$ & $\begin{array}{l}\mathrm{pN}+, 70.5 \% \\
\mathrm{pN2}, 47.7 \%\end{array}$ & $38.0 \%$ & - & - & - & - & - & - & - & $\begin{array}{l}5 \text {-year } \\
\text { Os, } 40.3 \%\end{array}$ & - \\
\hline $\begin{array}{l}\text { Liang, } \\
2017 \text { [91] }\end{array}$ & $1990-2010$ & $\begin{array}{l}\text { Retro. Single-center } \\
\text { (China) }\end{array}$ & $\begin{array}{c}37 \\
(1.4 \%)\end{array}$ & 50 (median) & $1.5: 1$ & $48.6 \%$ & $5.4 \%$ & $45.9 \%$ & - & $89.1 \%$ & $\begin{array}{l}\mathrm{pN}+70.3 \% \\
\mathrm{pN2}, 51.2 \%\end{array}$ & - & $66.7 \%$ & - & $19.1 \%$ & $4.8 \%$ & $4.8 \%$ & & $9.6 \%$ & $\begin{array}{l}\text { 5-year } \\
\text { OS, 10.8\% }\end{array}$ & $\begin{array}{l}\text { Mean OS, } \\
27.1 \pm 3.3 \mathrm{~ms}\end{array}$ \\
\hline $\begin{array}{l}\text { Korphaisarn, } \\
2019[20]]\end{array}$ & 2009-2015 & $\begin{array}{l}\text { Retro. } \\
\text { Single-center } \\
\text { +UTMDACC registry }\end{array}$ & $35^{\#}$ & 55 (median) & $0.9: 1$ & $62.9 \%$ & $37.1 \%(1$ & ft-sided) & $100 \%$ & $100 \%$ & - & - & $82.9 \%$ & - & $17.1 \%$ & $17.1 \%$ & - & - & - & - & $\begin{array}{l}\text { Median OS, } \\
16.4 \mathrm{~ms}\end{array}$ \\
\hline 'Shi, $2019[4]$ & 2010-2014 & Review of SEER data & $\begin{array}{c}1,932 \\
(1.11 \%)\end{array}$ & $<65,48.24 \%$ & 1.1:1 & - & - & - & $93.14 \%$ & 77.93\% & $\mathrm{pN}+64.38 \%$ & - & $17.65 \%$ & - & $6.88 \%$ & $2.80 \%$ & $3.05 \%$ & - & $11.60 \%$ & - & $\begin{array}{l}\text { (PM cases) } \\
\text { Median OS, } \\
9 \text { ms; Median } \\
\text { CSS, } 10 \mathrm{~ms}\end{array}$ \\
\hline $\begin{array}{l}\text { 'Benesch, } \\
2020[]]\end{array}$ & 1975-2016 & Review of SEER data & $\begin{array}{l}4,586 \\
(1.0 \%)\end{array}$ & $65.2 \pm 16.4$ & $1.0: 1$ & $\begin{array}{l}\text { Only colon } \\
\text { include }\end{array}$ & & - & $93.0 \%$ & - & - & - & - & - & - & - & - & - & - & $\begin{array}{l}\text { 5-year } \\
\text { OS, 33.6\% } \\
10-\text { year } \\
\text { OS, 28.6\% }\end{array}$ & $\begin{array}{l}\text { Median OS, } \\
21.6 \mathrm{~ms}\end{array}$ \\
\hline $\begin{array}{l}\text { YYang, } \\
2020[30]\end{array}$ & 2004-2015 & Review of SEER data & $\begin{array}{l}3,278 \\
(\mathrm{NA})\end{array}$ & 63 (median) & $1.0: 1$ & $63.19 \%$ & $16.41 \%$ & $20.40 \%$ & $93.46 \%$ & $81.27 \%$ & $\begin{array}{l}\text { pN+, 73.03\% } \\
\mathrm{pN} 2,70.41 \%\end{array}$ & - & - & - & - & - & - & - & - & $\begin{array}{l}\text { 5-year OS, } \\
25.14 \% \\
5 \text {-year CSS, } \\
29.32 \% \text {. }\end{array}$ & $\begin{array}{l}\text { Median OS, } \\
16.0 \mathrm{~ms}\end{array}$ \\
\hline
\end{tabular}

SRCC, signet ring cell carcinoma; M, male; F, female; LN, Iymph node; Retro., retrospective; OS, overall survival; RS, Relative Survival; NA, not available; CSS, cancer-specific survival; *, There is gender bias in this database; *, all patients were with stage IV tumors; PM, peritoneal metastasis. ${ }^{\dagger}$, The four articles are all based on SEER database with overlapping time frames. The included patients could be partially duplicated. Due to differences in inclusion/exclusion criteria, analysis parameters, study methods, and time spans, all the four studies are included. 


\begin{tabular}{|c|c|c|}
\hline \multirow[b]{2}{*}{$\begin{array}{l}\text { Clinicopathological } \\
\text { characteristics }\end{array}$} & SRCC & AC \\
\hline & & \\
\hline Prevalence & $\sim 1 \%$ of CRC & $\sim 90 \%$ of CRC \\
\hline Onset age & Younger (median, 65.0ys) & Older (median, 68.5ys) \\
\hline Male/female ratio & 1:1 & $1.3: 1$ \\
\hline Tumor size & Relatively larger & Relatively smaller \\
\hline Histological grade & Higher & Lower \\
\hline Tumor stage & More advanced & Less advanced \\
\hline $\mathrm{LN}$ involvement rate & Higher & Lower \\
\hline Neurovascular infiltration rate & Higher & Lower \\
\hline Right-side located & More frequent & Less frequent \\
\hline Metastasis rate & Higher & Lower \\
\hline \multicolumn{3}{|l|}{ Metastatic pattern } \\
\hline Peritoneum, diffusely & More & Less \\
\hline Prognosis & Very poor & Relatively better \\
\hline
\end{tabular}

FIGURE 1 | Comparison of clinicopathological characteristics between SRCC and AC [4-6,20,91]. The above endoscopic and CT images are selected by the authors from the clinical database of Peking Union Medical College Hospital. Related patients have provided written informed consents for publication of their clinical data. Adobe Illustrator CC 2018 was used to create the artwork.

easily spread and form diffuse disseminations instead of forming larger metastatic foci $[15,27,33,35]$.

\section{PROGNOSIS}

Colorectal SRCC has been associated with significantly worse prognosis than AC in terms of higher local and distant recurrence rate, shorter cancer-specific survival (CSS) and overall survival (OS) $[5,7,8,14,16,24,36]$. Most studies describe an over 50\% increased hazard ratio (HR) of death from cancer compared to AC $[5,6,14,16]$. Prognostic factors that strongly correlated with the poor outcomes have been widely discussed. Among them, advanced stage at diagnosis is consistently believed the main reason for the poor prognosis. However, the prognostic value of SRC histology remains controversial. After adjustment for covariates including tumor stage and location, SRC histology has been shown an independent adverse prognostic factor in most studies $[5,6,8,16,20,36,37]$. While there are still a few authors who believe that the poor outcome only comes from the advanced stage at diagnosis and question the role of tumor biology in it [14,22]. Mizushima et al. [38] reported that patients with stage III colorectal SRCC had significantly worse survival than those with AC, while no such difference was observed in stage II or IV tumors. A population-based study including 1,972 colorectal SRCC cases demonstrated that SRCC was associated with significantly worse 5-year relative survival than AC. This survival difference was found in both stage II and III cases, but was most prominent in stage III [5].
Additionally, the high rate of synchronous and metachronous distant metastasis associated with the histological subtype has been supposed an important reason for the bleak prognosis of colorectal SRCC $[5,8,39,40]$. For patients with diffuse distant metastasis (most common as peritoneal dissemination), their disease can neither be radically removed by surgery, nor can it be effectively controlled by chemotherapy [41], which lead to the dismal outcomes of patients.

\section{MOLECULAR CHARACTERISTICS OF SIGNET RING CELL CARCINOMA}

In addition to having special clinicopathological characteristics, colorectal SRCC is also different from AC for the molecular features. Some authors suggested that SRCs may arise from a separate genetic pathway [35]. Due to the rarity of this subtype, both the number and sample size of studies focusing on its molecular abnormalities are very small. Although a thorough understanding and consensus has not yet been formed, some studies have analyzed and summarized the genetic, epigenetic, and protein expression characteristics of colorectal SRCC, which may contribute to the understanding of the carcinogenesis mechanism of SRCC, and may explain the unique clinicopathological characteristics and the poor prognosis of this particular subtype. A summary of previous studies upon the molecular features of colorectal SRCC is shown in Table 2 and Figure 2. 
TABLE 2 | Molecular features of colorectal signet ring cell carcinoma.

\begin{tabular}{|c|c|c|c|c|c|c|c|c|c|c|c|c|c|c|c|c|c|c|c|c|c|c|c|}
\hline Study & Country & $\begin{array}{l}\text { Sequencing } \\
\text { assay }\end{array}$ & No. & Stage & $\begin{array}{c}\text { SRC } \\
\text { component } \\
(\%)\end{array}$ & $\begin{array}{l}\text { Site, } \\
\text { P:D }\end{array}$ & $\begin{array}{c}\text { KRAS } \\
(\%)\end{array}$ & $\begin{array}{l}\text { NRAS } \\
(\%)\end{array}$ & $\begin{array}{l}\text { BRAF } \\
(\%)\end{array}$ & $\begin{array}{l}\text { PIK3CA } \\
(\%)\end{array}$ & $\begin{array}{l}\text { APC } \\
(\%)\end{array}$ & $\begin{array}{l}\text { TP53 } \\
(\%)\end{array}$ & $\begin{array}{c}\text { SMAD4 } \\
(\%)\end{array}$ & $\begin{array}{c}\text { RNF43 } \\
(\%)\end{array}$ & $\begin{array}{l}\mathrm{KIT} \\
(\%)\end{array}$ & $\begin{array}{l}\text { CDH1 } \\
(\%)\end{array}$ & $\begin{array}{c}\text { MSI- } \\
\text { H } \\
(\%)\end{array}$ & $\begin{array}{c}\text { MSI-H } \\
\text { tumor } \\
\text { site, } \\
\mathrm{P}: \mathrm{D}\end{array}$ & $\begin{array}{c}\text { dMMR } \\
(\mathrm{IHC}) \\
(\%)\end{array}$ & $\begin{array}{l}\text { CIMP } \\
\text { positive } \\
(\%)\end{array}$ & $\begin{array}{l}\text { p16 } \\
\text { loss } \\
(\%)\end{array}$ & $\begin{array}{l}\text { MLH1 } \\
\text { loss } \\
(\%)\end{array}$ & $\begin{array}{l}\text { LOH } \\
\text { positive } \\
(\%)\end{array}$ \\
\hline $\begin{array}{l}\text { Kawabata, } \\
1999 \text { [92] }\end{array}$ & Japan & PCR-RFLP & 10 & $\|-I V$ & NA & $0.25: 1$ & 11 & & & & & $\begin{array}{l}29 \% \\
(\mathrm{HC})\end{array}$ & & & & & 30 & $2.0: 1$ & & & & & \\
\hline $\begin{array}{l}\text { Kakar, } \\
2005[75]\end{array}$ & United States & PCR & 72 & $\mathrm{I-IV}$ & $>50 \%$ & $1.26: 1$ & & & & & & & & & & & 31 & 4.3:1 & 29 & & & $\begin{array}{l}29 \% \\
(\mathrm{HC})\end{array}$ & \\
\hline $\begin{array}{l}\text { Ogino, } \\
2006 \text { [60] }\end{array}$ & United States & WGA-PCR & 39 & NA & Any & $\mathrm{NA}$ & 26 & & 28 & & & $\begin{array}{l}50 \% \\
(\mathrm{HC})\end{array}$ & & & & & 31 & - & & & $\begin{array}{l}29 \% \\
(\mathbb{H C})\end{array}$ & $\begin{array}{l}30 \% \\
(\mathrm{HC})\end{array}$ & $\begin{array}{c}18 q \\
\text { LOH, } 38 \%\end{array}$ \\
\hline $\begin{array}{l}\text { Sung, } \\
2008 \text { [27] }\end{array}$ & Korea & PCR & 63 & $\|-\mathrm{IV}$ & $>50 \%$ & $0.55: 1$ & & & & & & & & & & & 19 & $2.0: 1$ & & & & & \\
\hline $\begin{array}{l}\text { Kakar, } \\
2012[28]\end{array}$ & United States & PCR & 33 & $\mathrm{H}-\mathrm{IV}$ & $>50 \%$ & $0.94: 1$ & 53 & & 33 & & & & & & & & 24 & $3.0: 1$ & & 48 & & & $\begin{array}{l}\text { Any of the } 4 \\
\text { loci, } 93 \% \text {; } \\
18 \mathrm{q} \\
\text { LOH, } 40 \%\end{array}$ \\
\hline $\begin{array}{l}\text { Hartman, } \\
2013 \text { [76] }\end{array}$ & United States & PCR & 53 & $\mathrm{H}-\mathrm{IV}$ & $>50 \%$ & $1.79: 1$ & & & 30 & & & & & & & & 43 & $3.6: 1$ & & & & $\begin{array}{l}35.8 \% \\
(\mathrm{HC})\end{array}$ & \\
\hline $\begin{array}{l}\text { Inamura, } \\
2015[61]\end{array}$ & United States & $\begin{array}{l}\text { PCR } \\
\text { Pyrosequencing }\end{array}$ & 17 & I-IV & $>50 \%$ & $2.80: 1$ & 5.9 & & 35 & 6.3 & & & & & & & 29 & - & & 29 & & $29 \%$ & \\
\hline Wei, 2016 [58] & China & NGS & 61 & I-IV & Any & $0.69: 1$ & 16.7 & 5.4 & 3.7 & & 31.5 & & 40.7 & & & 24.1 & & & & & & $16.7 \%$ & \\
\hline Alvi, 2017 [62] & $\begin{array}{l}\text { Northern } \\
\text { Ireland }\end{array}$ & $\begin{array}{l}\text { NGS, } \\
\text { Sanger seq. }\end{array}$ & 44 & $\mathrm{I-IV}$ & $>50 \%$ & $1.59: 1$ & 12 & & 31 & 4 & 35 & $69 \%$ & & & 34 & & 48 & $9.0: 1$ & & 41 & & & \\
\hline $\begin{array}{l}\text { Yalcin, } \\
2017[77]\end{array}$ & Turkey & $\begin{array}{l}\text { PCR-RFLP } \\
\text { Sanger seq. }\end{array}$ & 28 & $\|-I V$ & Any & $0.87: 1$ & & & 39.3 & & & & & & & & & & & & & & \\
\hline $\begin{array}{l}\text { Nam, } \\
2018 \text { [45] }\end{array}$ & Korea & WES RNA seq. & 5 & $\|-I V$ & $>50 \%$ & $0.25: 1$ & 40 & 0 & 0 & 0 & 20 & $40 \%$ & 20 & & & & & & & & & & \\
\hline Kim, 2019 [59] & Korea & $\begin{array}{l}\text { Targeted } \\
\text { panel NGS }\end{array}$ & 17 & I-III & Any & $0.55: 1$ & 23.5 & & 5.9 & 5.9 & 23.5 & $47.1 \%$ & 29.4 & & & & 0 & - & & & & & \\
\hline $\begin{array}{l}\text { Korphaisarn, } \\
2019 \text { [20] }\end{array}$ & United States & NGS & 35 & IV & $\geq 50 \%$ & $1.70: 1$ & 11.4 & 0 & 8.6 & 2.9 & 2.9 & $60.0 \%$ & 14.3 & & & & 12.1 & - & 12.1 & 33.3 & & & \\
\hline Li, 2020 [44] & China & WES & 29 & $\|-I V$ & $>70 \%$ & $0.26: 1$ & 10.3 & & 6.9 & 0 & 3.4 & $55.2 \%$ & 20.7 & 34.5 & & & 3.4 & - & & & & & \\
\hline $\begin{array}{l}\text { Chen, } \\
2020 \text { [93] }\end{array}$ & China & NGS & 18 & I-IV & Any & $1.57: 1$ & 11.1 & 11.1 & 5.6 & 22.2 & 27.8 & $55.6 \%$ & 11.1 & & 0 & & & & 0 & & & & \\
\hline
\end{tabular}

SRC, signet ring cell; P:D, proximal colon: distal colon and rectum; MSI-H, microsatellite instability-high; dMMR, deficient mismatch repair; IHC, immunohistochemistry; CIMP, CpG island methylator phenotype; LOH, Ioss of heterozygosity; PCR, polymerase chain-reaction; RFLP, restriction-fragment length polymorphism; NA, not available; WGA, whole genome amplification; NGS, next generation sequencing; WES, whole exome sequencing; seq., sequencing. 


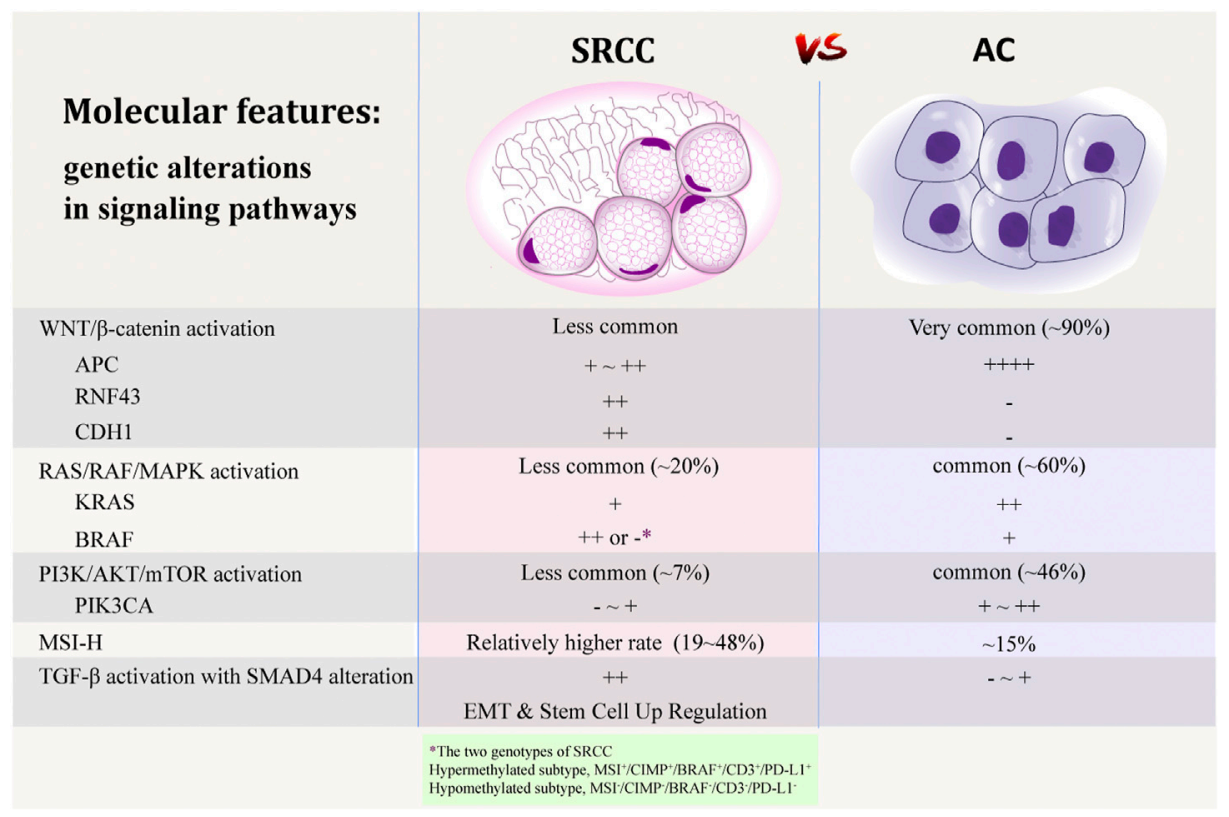

FIGURE 2 | Comparison of molecular features between SRCC and AC [20,44,45,58-60,72,75,93]. Adobe illustrator CC 2018 was used to create the artwork.

\section{ADENOMATOUS POLYPOSIS COLI MUTATION AND WNT/ $\beta$-CATENIN SIGNALING PATHWAY}

Adenomatous polyposis coli $(A P C)$ is a key tumor suppressor gene, which plays a critical early role in the tumorigenesis of most CRC [42]. Aberrant inactivation of $A P C$ results in activation of the $\mathrm{WNT} / \beta$-catenin signaling pathway, which is a common event in the colorectal adenoma-carcinoma sequence [18]. Genomic analyses have shown that WNT pathway is altered in $93 \%$ of all CRC, including biallelic inactivation of $A P C$ or activating mutations of CTNNB1 in $\sim 80 \%$ of cases [43]. However, colorectal SRCC is strikingly different from AC in terms of the mutated genes in the WNT pathway, showing significantly lower frequency of APC mutation [20,43-45].

Being a critical component of WNT pathway, $\beta$-catenin shows inappropriate stabilization and translocation to the nucleus when the signaling pathway is upregulated, which is considered a biomarker of WNT pathway activation [46-48]. Apart from APC, other genes in the WNT pathway were also found significantly less mutated in colorectal SRCC than those in AC, which included $\beta$-catenin target genes LGR5, SOX9, AXIN2, and MSI1 [44]. However, study of Börger et al. using immunohistochemical analysis observed that the membranous localization of $\beta$-catenin was reduced and its nuclear expression was present in colorectal SRCC [35], which showed that the $W N T / \beta$-catenin signaling pathway may also be activated in SRCC. It is therefore proposed that the WNT pathway may be activated through alternative pathways in SRCC, in the absence of $A P C$ mutation. RNF43, another key regulator of WNT pathway, encodes transmembrane molecules that attenuate WNT signaling [48]. Li et al. observed that SRCC was associated with frequent mutations in RNF43, with nonsense mutations (p.Glu43* and p.
Arg132*) enriched at the N-terminus, regardless of mutation burden. They proposed that SRCC may prefer a complete inactivation of RNF43 to activate $\mathrm{WNT} / \beta$-catenin pathway, instead of through $A P C$ mutation [44]. $C D H 1$, encoding the cell adhesion protein E-cadherin, is commonly mutated in gastric SRCC. Studies have shown that $\mathrm{CDH} 1$ loss activates WNT signaling by unleashing membrane-bound $\beta$-catenin, which in turn activates the WNT/ $\beta$-catenin pathway $[47,49-51]$. In colorectal SRCC, CDH1 mutation occurs in a proportion of cases and is found to be associated with reduction in E-cadherin in these tumors [52]. CDH1 mutation may therefore be another alternative mechanism of WNT pathway activation in some colorectal SRCC. Besides, alterations of DKK4, FZD10, AMER1, and AXIN2 may also contribute to $\beta$-catenin activation in SRCC, in the absence of $A P C$ and RNF43 mutation [44]. In all, carcinogenesis driven by WNT pathway appear to be present in SRCC, often through mechanisms apart from APC mutation. The related molecular mechanisms need to be further investigated.

\section{RAS/RAF/MAPK SIGNALING PATHWAY}

RAS/RAF/MAPK signaling is another important pathway in the colorectal adenoma-carcinoma sequence. Activating mutations in oncogene KRAS lead to a constitutively activated kinase cascade, resulting in EGFR-independent activation of the mitogen-activated protein kinase (MAPK) pathway and uncontrolled cell proliferation [46,53]. Oncogene BRAF is another component of RAS/RAF/MAPK pathway. Activating mutation of $B R A F$ also results in signaling of this pathway [54,55]. In general, KRAS mutations occur in $30-40 \%$ of all CRC while BRAF mutations occur in 5-15\% [54-58]. 
Signaling through this same pathway, mutations in KRAS and $B R A F$ are both associated with poor prognosis in CRC and resistance to the treatment with EGFR inhibitors [53,54]. In addition, mutations of the two genes are mutually exclusive $[55,56]$.

It has been recognized that most CRC containing $B R A F$ (mostly BRAF V600E) have a CpG island methylator phenotype (CIMP), which is characterized by aberrant promotor methylation of many genes. By mediating the $M L H 1$ promotor methylation and epigenetic silencing this mismatch repair (MMR) gene, $B R A F$ mutation has a strong correlation with MSI-H phenotype in sporadic CRC [55-57].

In a pathway analysis including 29 colorectal SRCC, mutation rates of several cancer driver genes were dramatically different between different histology subtypes. In SRCC, the mutation load in MAPK pathway was significantly lower than that of AC $(20.7 \%$ vs. $60.5 \%$, respectively) [44].

Many studies have shown that compared to AC, KRAS mutation is less common in colorectal SRCC $[20,39,44,45,58,59]$. Whereas some other studies revealed that there is no significant difference in the frequency of KRAS mutation between SRCC and AC [28,60].

As for the frequency of BRAF alteration in colorectal SRCC, previous studies also reported discrepant results. Many studies have reported significantly higher frequency of $B R A F$ mutation in SRCC compared to AC. In addition, they invariably demonstrated a significant correlation between $B R A F$ mutation and CIMP positive status and reported a relatively high incidence of MSI-H phenotype (24-48\%) in colorectal SRCC [28,60-62]. However, some other studies have presented the opposite results. In a study including thirty-three patients with metastatic colorectal SRCC, BRAF mutation was observed in $8.6 \%$ cases and MSI-H status was found in $12.1 \%$ cases, which were comparable to those of AC [20]. In a Chinese cohort involving 61 cases of colorectal SRCC, BRAF mutation was identified in only $3.7 \%$ cases [58]. In a study conducting a comprehensive analysis of five colorectal SRCC using whole-exome and RNA sequencing analysis, none of the cases showed $B R A F$ mutation and the authors attributed it to the microsatellite stable (MSS) status of all those cases [45]. Similarly, in a study analyzing only MSS/sporadic CRC, none of the eight SRCC demonstrated BRAF mutation [18]. In the comprehensive molecular pathology research of Alvi et al., features including somatic mutations, DNA methylation, MSI status, and biomarkers reflecting the tumor immune microenvironment (TIME) were analyzed in 44 cases of colorectal SRCC [62]. They found significant correlations between the hypermethylated genotype and CIMP positive, MSI-H, BRAF V600E mutation, female gender, advanced age, and proximal tumor location. Accordingly, they proposed that SRCC comprises two distinct genotypes, an $\mathrm{MSI}^{+} /$ $\mathrm{CIMP}^{+} / B R A F^{+} / \mathrm{CD}^{+} / \mathrm{PD}^{-\mathrm{L}^{+}}{ }^{+}$hypermethylated genotype predominantly in the proximal colon and a hypomethylated genotype mostly in the distal colon, among which the hypermethylated subgroup may benefit from the immune checkpoint inhibitor (ICI) therapy [62]. As shown in Table 2, there are divergent results in the molecular characteristics of colorectal SRCC among different studies. We speculate that these differences may be largely due to the different proportions of the two methylation subtypes in different cohorts.

\section{PIK3CA AND PI3K/AKT/MTOR SIGNALING PATHWAY}

The phosphatidylinositol 3-kinase $(\mathrm{PI} 3 \mathrm{~K}) /$ protein kinase $\mathrm{B}$ $(\mathrm{AKT}) /$ mammalian target of rapamycin (mTOR) signaling pathway plays an important role in carcinogenesis, which is abnormally activated in various types of cancer. Phosphatidylinositol-4,5-bisphosphonate 3-kinase, catalytic subunit alpha polypeptide (PIK3CA), a gene encodes the p110a catalytic subunit of PI3K, plays an important role in the $\mathrm{PI} 3 \mathrm{~K} / \mathrm{AKT} / \mathrm{mTOR}$ pathway. Mutations in PIK3CA are present in approximately $15-20 \%$ of CRC, making it one of the major driver oncogenes in CRC $[63,64]$. In addition, PIK3CA mutations commonly coexist with KRAS mutations and lead to additive activation of the PI3K pathway [65]. In colorectal SRCC, lower frequency $[59,61]$ or even absence [20,44,45] of PIK3CA mutation were reported. Li et al. [44], performed whole exome sequencing (WES) on 29 cases of SRCC and found that mutation of PI3K pathways is lower in SRCC compared to AC (6.9\% vs. $46.1 \%)$. Mutations in PIK3CA, PTEN and IRS2 were almost absent in SRCC. In addition, studies performing WES and gene panel sequencing analyses revealed that most driver genes associated with CRC, including $A P C$, $K R A S$, and PIK3CA, are mutated at lower rates in SRCC $[20,44,45]$.

\section{SMAD4 AND TGF- $\beta$ SIGNALING PATHWAY}

SMAD4 is a tumor suppressor gene that regulates gene transcription and cell growth. It has been reported that CRC with loss of SMAD4 expression is associated with aggressive tumor behavior, poor prognosis and chemoresistance to 5fluorouracil-based therapy, as well as decreased tumoral and peritumoral immune infiltration $[59,66]$. In colorectal SRCC, frequent SMAD4 alteration $(20-30 \%)$ has been reported in several studies $[20,44,45,59]$, which seems to be more common in comparison with AC $(\sim 10 \%)$ [67]. Being a component of SMAD transcriptional complex, SMAD4 acts as a major regulator of the transforming growth factor- $\beta$ (TGF- $\beta$ ) signaling pathway. In response to TGF- $\beta$, SMAD complex induces the epithelialmesenchymal transition (EMT) process directly and indirectly. EMT, a process being characterized by destruction of epithelial cell junction and alteration of cell polarity, consequently generation of invasive cells with stem-cell like properties, is considered a key player in promoting tumor invasion and dissemination [45,68]. A study performing a gene set enrichment analysis (GSEA) revealed that SRCC-specific upregulated genes were enriched in the EMT and the "Stem Cell Up Regulation" processes [45]. Additionally, decreased E-cadherin expression and increased $\mathrm{N}$-cadherin expression were observed in the tumor tissue of SRCC, which indicated the involvement of EMT process in tumorigenesis of SRCC [45]. 
SRCC with aberrant activated TGF- $\beta /$ SMAD4 signaling pathway represents a refractory cancer subtype. Although there has been no medication targeting the loss of SMAD4, a few studies have shown the link between SMAD4 loss and response to specific chemotherapeutic drugs such as topoisomerase inhibitors [69]. In addition, agents targeting the TGF- $\beta /$ SMAD4 pathway may be another potential therapy [70].

\section{MICROSATELLITE INSTABILITY STATUS, CPG ISLAND METHYLATOR PHENOTYPE, AND CHROMOSOMAL INSTABILITY}

It has been recapitulated that $\sim 15 \%$ of CRC are MSI-H, which include $\sim 3 \%$ of inherited cancer susceptibility syndrome (predominantly Lynch syndrome) and $\sim 12 \%$ of sporadic CRC mainly due to silencing of the MMR genes (mostly by promotor methylation of MLH1) [56,57,71,72]. CRC with MSI-H is associated with advanced age, female gender, the proximal colon, poor differentiation, mucinous or SRC histology, BRAF mutation and CIMP positive status, as well as a better prognosis compared to CRC without MSI-H [72-74].

Despite small sample sizes, a number of studies have demonstrated that compared to AC, colorectal SRCC has a higher proportion of MSI-H phenotype, with a proportion of $19-48 \%$ according to literatures (Table 2) $[28,60-62,75,76]$. In contrast to the favorable prognostic value of MSI-H, the SRC histology is a well-accepted poor survival predictor. Most of the studies have shown that in colorectal SRCC, the MSI-H status does not appear to be a significant predictor of survival $[27,75,76]$.

Kakar et al. [28] observed that different from the MSI-H AC, colorectal SRCC with MSI-H status has a significantly higher prevalence of chromosomal instability (CIN). This can be reflected by the fact that the loss of heterozygosity (LOH) presents in $80 \%$ of MSI-H SRCC and in only $14 \%$ of MSI-H AC. It was speculated that the aggressiveness of CIN phenotype outweighs any favorable effects of MSI-H in SRCC [28,75].

The CIMP is a distinct epigenotype which is characterized by widespread promoter methylation and silencing of tumor suppressor genes by methylation of their promoters. CIMP positive CRC commonly presents with MSI-H status due to methylation of $M L H 1$ and is associated with BRAF mutation $[56,74]$. Stratified with stage, improved cancer-specific survival (CSS) has been observed in CIMP positive CRC regardless of MSI status and BRAF mutation [74]. A number of studies have shown that CIMP positive status and $B R A F$ mutation are more frequent in colorectal SRCC compared to AC $[28,60,61,77]$. According to the classification by methylation status $[43,62]$, however, the CIMP positive SRCC seems to represent one of the two subtypes of colorectal SRCC, the hypermethylated genotype.

CIN is a gross genetic mutation that occurs at the chromosomal level, presenting as aneuploid or polyploid karyotype as well as multiple structural chromosomal changes such as translocations, allelic losses and amplifications [71,78]. CIN status strongly correlates with worse prognosis [71]. $\mathrm{LOH}$ is when one of a pair of alleles at a specific locus is missing, which is closely related to $\mathrm{CIN}$, with $\mathrm{LOH}$ appearing frequently in
CIN-high cases [78]. CRC with MSI-H tend to be diploid and CIN is not generally believed a major mechanism for the carcinogenesis of MSI-H CRC [28,71]. Being a common late event of colorectal carcinogenesis, $18 \mathrm{q} \mathrm{LOH}$ was reported to be less frequent in SRCC $(4 / 7,57 \%)$ compared to AC $(194 / 304,64 \%)$ [60]. In contrast, Kakar et al. reported a higher $\mathrm{LOH}$ positive rate in SRCC than that in AC (93\% vs. 70\%, $p=0.04)$, with $18 \mathrm{q} \mathrm{LOH}$ being found most frequent $(6 / 17,35.3 \%)$ in SRCC. Additionally, they did not observe significant difference in LOH between SRCC with MSI-H or MSS phenotype ( $80 \%$ vs. $100 \%, p=0.3)$. The author argued that CIN, as manifested by $\mathrm{LOH}$, is present in nearly all SRCC, including those with MSI-H [28].

Due to the limited number of publications, the related issues need further research to clarify.

\section{TUMOR IMMUNOLOGY IN SIGNET RING CELL CARCINOMA}

It is increasingly recognized that the response of tumors to immunotherapies and most conventional anti-cancer therapies is associated with the immune contexture, which is determined by the density, composition, functional status and organization of immune cell infiltration within a tumor $[79,80]$. Introduction of checkpoint inhibitor (ICI) therapy provides remarkable achievements in multiple types of MSI-H or high tumor mutation burden(TMB-H) tumors. CRC patients with MSI-H have been well recognized as good candidates for ICI therapy [62,81]. In the study of Alvi et al. [62], adaptive immunity (CD3) and the immune checkpoint (PD-L1) were tested through immunohistochemistry (IHC) to evaluate the adaptive immune resistance in 44 cases of colorectal SRCC. In this cohort, colorectal SRCC was subclassified into hypermethylated (41\%) and hypomethylated groups (59\%) according to the DNA methylation status. The results showed that colorectal SRCC with MSI-H had a significantly higher infiltration of $\mathrm{CD}^{+}$T-lymphocytes and a higher PD-L1 expression compared to the MSS tumors. Similar trends were also observed in the $\mathrm{MSI}^{+} / \mathrm{CIMP}^{+} / B R A F^{+} / \mathrm{CD}^{+} / \mathrm{PD}-\mathrm{L}^{+}$ hypermethylated group compared to the hypomethylated group. They concluded that the hypermethylated genotype of colorectal SRCC is an ideal candidate for the ICI therapy [62].

\section{SIGNET RING CELL CARCINOMA IN RECTUM}

Epidemiological data show that rectal cancer accounts for $27-29 \%$ of all CRC in general $[5,6,16]$. In terms of SRC histology, rectal SRCC accounts for $17-21 \%$ of all colorectal SRCC cases $[5,6,16,30]$, which indicates that the proportion of SRCC in the rectum is relatively lower. Analysis of the SEER data reveals that despite a stable incidence of rectal cancer for all ages, the incidence in patients under 40 has quadrupled from 1980 to 2010, and cancers in this group are 3.6 times more likely to have SRC histology [9]. These data indicate that incidence of rectal SRCC is increasing during the past decades, particularly in 
younger population. Unlike colon SRCC which occurs with approximately equal incidence in men and women, rectal SRCC is more common in men, with a male-to-female ratio of 1.6-2.1:1 [6,7,22]. Studies have shown that rectal SRCC is more aggressive, showing significantly worse survival, compared to colon SRCC $[5,14,16]$. A study based on the SEER database showed that rectal SRCC had significantly lower 5-year relative survival (5-y RS) rates compared to colon SRCC (21.1\% vs. $28.6 \%)$ [16]. Another nationwide population-based study of Netherlands Cancer Registry (NCR) achieved quite similar results, showing the $5-\mathrm{y}$ RS of $19.5 \%$ and $30.8 \%$ for rectal and colon SRCC, respectively [5]. Studies have shown that similar to the conventional CRC, SRCC in the right-sided (proximal) colon and left-sided (distal) colorectum also have different clinicopathological and molecular characteristics. SRCC with MSI-H status was significantly more frequently observed in the proximal colon than the distal colorectum, as shown in Table 2 [27,62,75,76]. In addition, poorly differentiated adenocarcinoma/MAC/SRCC of the proximal colon was reported to have significantly better DFS than distal cancers [82]. According to Alvi et al.'s classification of colorectal SRCC [62], rectal SRCC, as a part of distal SRCC, seems to be more in line with the hypomethylated genotype. Besides, rectal SRCC may also have some other unique features. Being a distinctive entity with an increased incidence in the young population, rectal SRCC deserves further investigations.

\section{CARCINOMAS WITH SIGNET RING CELL COMPONENT}

SRCC is defined as the presence of more than $50 \%$ of SRCs in the tumor. AC containing SRC component of less than 50\% represents a substantial subgroup, but there is currently no formal SRCC designation for it [20]. In the study of Korphaisarn et al., the frequencies of somatic gene mutations in AC with SRC component varied between those observed in SRCC and AC. The author attributed this to the mixture of different components during tissue selection process and strongly recommended to define the patient as either SRCC or AC with SRC component [20]. In some other studies, however, no significant difference was observed for the clinicopathological and genetic characteristics between AC with SRC component of less than $50 \%$ and those with $\geq 50 \%[58,60,77]$. In terms of clinical outcomes, most studies concluded that the SRC histology is associated with a significant poor survival of CRC patients, regardless of the percentage of SRC component $[15,20,27,58,61,77]$. Pande et al. proposed that the SRC component seems to confer the predisposition of the widespread metastatic pattern, which may explain the consistent poor prognosis of AC with SRC component, regardless of the proportion of SRCs [15].

Colorectal SRCC with different amount of extracellular mucin has also been investigated. Hartman et al. [76] designated colorectal SRCC into mucin-poor (extracellular mucin $\leq 49 \%$ ) and mucin-rich (extracellular mucin $>50 \%$ ) subgroups. Their study showed that the mucin-poor SRCC was characterized by the high frequency of lympho-vascular invasion and perineural infiltration, and significantly reduced survival compared to the mucin-rich group. Additionally, MSI-H status was mostly found in the mucin-rich group. However, in a study including 72 cases of colorectal SRCC, no significant difference in the MSI status was observed between tumors with $\geq 70 \%$ of extracellular mucin and those with $<70 \%$. And the article did not mention why $70 \%$ was used as the cutoff value [75]. It seems that subgrouping of SRCC according to the amount of extracellular mucin and its related clinical significance are worthy of further study.

\section{TREATMENT}

Due to the relatively higher stage at diagnosis, Patients with SRCC are more likely to receive multimodality treatment including chemotherapy and radiotherapy $[5,6,8,83]$. Despite poor outcomes, studies have shown that patients with colorectal SRCC can benefit from chemotherapy. In a large-scale study that included 1,972 SRCC patients, Hugen et. al [5]. found that adjuvant fluorouracil-based chemotherapy for stage III colon cancer yielded similar benefits for the conventional and SRC subtypes. A recent study including 1,675 patients with stage II/III colorectal SRCC showed that postoperative chemotherapy was an independent prognostic factor for better CSS and OS (CSS: HR = $0.719,95 \%$ CI $0.612-0.844, p<0.001)$; (OS: HR $=0.618,95 \% \mathrm{CI}$ 0.537-0.713, $p<0.001)$ [84].

Hugen et al. [5] proposed that chemotherapy benefits colorectal SRCC, the poor outcomes of patients may be related to the more advanced stage and the deviant metastatic pattern of SRCC. Peritoneal metastasis (PM), frequent in SRCC, represents a clinical difficulty that can hardly be treated with cure intent [5]. A population-based study revealed that compared to surgery, chemotherapy was associated with better survival for colorectal SRCC patients with PM [4]. Although with some benefits, the standard chemotherapeutic regimens for patients with PM are mostly palliative treatment that cannot cure the disease.

As for CRC with PM, it has been reported that cytoreductive surgery (CRS) with hyperthermic intraperitoneal chemotherapy (HIPEC) is beneficial for selected patients [85]. However, properly selecting candidates who may benefit from this treatment is very important. It was reported that improved survival was only observed when complete cytoreduction was achieved [86]. It has been shown that unfavorable factors in tumor biology, such as $R A S / R A F$ mutations, high-grade tumors, and SRC histology, are associated with worse survival in patients receiving CRS/HIPEC [87]. A number of prognostic scoring systems have been developed for optimal clinical practice, but no ideal scoring system has been recognized. Related issues are still being improved.

Studies have revealed that colorectal SRCC is a heterogeneous subgroup with different underlying molecular mechanisms. It is therefore important to perform individualized therapy according to the molecular characteristics of different patients. For instance, for tumors with loss of SMAD4 expression, regimens with topoisomerase inhibitors may be recommended. For SRCC with the $\mathrm{MSI}^{+} / \mathrm{CIMP}^{+} / \mathrm{BRAF}^{+} / \mathrm{CD}^{+} / \mathrm{PD}-\mathrm{L}^{+}$hypermethylated 
genotype, ICI therapy may be a potentially effective treatment [62]. In addition, systemic treatment with combined irinotecan (CPT-11)/panitumumab regimen was reported to be effective in an end-staged colon SRCC patient with disseminated carcinomatosis [34]. New medication targeting the specific signaling pathway or multiple pathways represents the future research direction.

Due to the special metastatic pattern of SRCC, which includes diffuse spread of small lesions and lower incidence of liver/ pulmonary metastasis, the follow-up plan for colorectal SRCC should also be different from that for AC. Physicians cannot rely solely on imaging studies including computed tomography (CT) scan or magnetic resonance imaging (MRI). It is recommended to pay more attention to the monitoring of tumor markers including cancer embryonic antigen (CEA) and carbohydrate antigen 19-9 (CA19-9). PET-CT can be performed at an earlier stage. In these patient groups, early detection of peritoneal metastases should be priority [15,32]. Besides, novel molecular markers such as circulating tumor DNA (ctDNA) can be used as promising monitoring indicators $[88,89]$.

\section{CONCLUSION}

As a rare but aggressive subtype of CRC, SRCC has distinct clinicopathological and molecular characteristics. Due to the unfavorable clinical features including advanced tumor stage at diagnosis, high tumor grade, high rate of lymph node involvement, early and diffuse distant metastasis, SRCC is associated with a bleak prognosis. In aspects of molecular biology, colorectal SRCC presents lower mutation burden in the canonical WNT, MAPK, and PI3K pathways, with most driver genes in conventional CRC (APC, KRAS, and PIK3CA, etc.) being mutated at lower rates in SRCC. In contrast, some SRCC-specific altered genes and signaling pathways were reported to be implicated in the "EMT" and "Stem Cell Up Regulation" processes (such as RNF43, CDH1, SMAD4, $\beta$-catenin and TGF- $\beta$ pathway), which were believed the reason of the aggressive tumor biology and the

\section{REFERENCES}

1. Arnold M, Abnet CC, Neale RE, Vignat J, Giovannucci EL, McGlynn KA, et al. Global Burden of 5 Major Types of Gastrointestinal Cancer. Gastroenterology (2020) 159(1):335-49. doi:10.1053/j.gastro.2020.02.068

2. Bray F, Ferlay J, Soerjomataram I, Siegel RL, Torre LA, and Jemal A. Global Cancer Statistics 2018: GLOBOCAN Estimates of Incidence and Mortality Worldwide for 36 Cancers in 185 Countries. CA: A Cancer J Clinicians (2018) 68(6):394-424. doi:10.3322/caac.21492

3. Laufman H, and Saphir O. Primary Linitis Plastica Type of Carcinoma of the colon. Arch Surg (1951) 62(1):79-91. doi:10.1001/ archsurg.1951.01250030082009

4. Shi T, Huang M, Han D, Tang X, Chen Y, Li Z, et al. Chemotherapy Is Associated with Increased Survival from Colorectal Signet Ring Cell Carcinoma with Distant Metastasis: A Surveillance, Epidemiology, and End Results Database Analysis. Cancer Med (2019) 8(4):1930-40. doi:10.1002/ cam4.2054 chemoresistance of SRCC. High frequency of BRAF mutation was observed in many studies of colorectal SRCC while it was not always the case. It was proposed that SRCC comprises two distinct genotypes, an $\mathrm{MSI}^{+} / \mathrm{CIMP}^{+} / B R A F^{+} /$ $\mathrm{CD}^{+} / \mathrm{PD}-\mathrm{L}^{+}{ }^{+}$hypermethylated genotype predominantly in the proximal colon and a hypomethylated genotype mostly in the distal colon, in which the hypermethylated subgroup is a potential candidate of the ICI treatment. The different proportions of the two methylation subtypes may explain the discrepancy in $B R A F$ mutation rates in different studies. For such a refractory disease, some new medication targeting the specific pathways of SRCC have been attempted. However, more in-depth researches are still needed to gain further understanding, in order to achieve substantial improvements in the treatment of this challenging disease.

\section{AUTHOR CONTRIBUTIONS}

YA, XQ, and WS did the literature research and selected relevant studies. YA, LC, and YL summarized clinicopathological and molecular features of signet ring cell carcinoma. JZ, GL, and HW reviewed the data and lead the analysis and discussion. JZ, GL, and YA wrote the manuscript. All authors contributed to the final revision of this manuscript.

\section{FUNDING}

This work was supported by the Major Grants Program of Beijing Municipal Science and Technology Commission (No. D171100002617003).

\section{CONFLICT OF INTEREST}

The authors declare that the research was conducted in the absence of any commercial or financial relationships that could be construed as a potential conflict of interest.

5. Hugen N, Verhoeven RH, Lemmens VE, van Aart CJ, Elferink MA, Radema SA, et al. Colorectal Signet-Ring Cell Carcinoma: Benefit from Adjuvant Chemotherapy but a Poor Prognostic Factor. Int J Cancer (2015) 136(2): 333-9. doi:10.1002/ijc.28981

6. Hyngstrom JR, Hu C-Y, Xing Y, You YN, Feig BW, Skibber JM, et al. Clinicopathology and Outcomes for Mucinous and Signet Ring Colorectal Adenocarcinoma: Analysis from the National Cancer Data Base. Ann Surg Oncol (2012) 19(9):2814-21. doi:10.1245/s10434-012-2321-7

7. Benesch MGK, and Mathieson A. Epidemiology of Signet Ring Cell Adenocarcinomas. Cancers (2020) 12(6):1544. doi:10.3390/cancers12061544

8. Nitsche U, Zimmermann A, Späth C, Müller T, Maak M, Schuster T, et al. Mucinous and Signet-Ring Cell Colorectal Cancers Differ from Classical Adenocarcinomas in Tumor Biology and Prognosis. Ann Surg (2013) 258(5):775-83. doi:10.1097/SLA.0b013e3182a69f7e

9. Tawadros PS, Paquette IM, Hanly AM, Mellgren AF, Rothenberger DA, and Madoff RD. Adenocarcinoma of the Rectum in Patients under Age 40 Is Increasing. Dis Colon Rectum (2015) 58(5):474-8. doi:10.1097/ DCR.0000000000000318 
10. Siegel RL, Jemal A, and Ward EM. Increase in Incidence of Colorectal Cancer Among Young Men and Women in the United States. Cancer Epidemiol Biomarkers Prev (2009) 18(6):1695-8. doi:10.1158/1055-9965.EPI-09-0186

11. Bailey CE, Hu C-Y, You YN, Bednarski BK, Rodriguez-Bigas MA, Skibber JM, et al. Increasing Disparities in the Age-Related Incidences of colon and Rectal Cancers in the United States, 1975-2010. JAMA Surg (2015) 150(1):17-22. doi:10.1001/jamasurg.2014.1756

12. Meyer JE, Narang T, Schnoll-Sussman FH, Pochapin MB, Christos PJ, and Sherr DL. Increasing Incidence of Rectal Cancer in Patients Aged Younger Than 40 Years. Cancer (2010) 116(18):4354-9. doi:10.1002/cncr.25432

13. Arai T. Where Does Signet-Ring Cell Carcinoma Come from and where Does it Go? Gastric Cancer (2019) 22(4):651-2. doi:10.1007/s10120-019-00960-w

14. Nitsche U, Friess H, Agha A, Angele M, Eckel R, Heitland W, et al. Prognosis of Mucinous and Signet-Ring Cell Colorectal Cancer in a Population-Based Cohort. J Cancer Res Clin Oncol (2016) 142(11):2357-66. doi:10.1007/ s00432-016-2224-2

15. Pande R, Sunga A, Levea C, Wilding GE, Bshara W, Reid M, et al. Significance of Signet-Ring Cells in Patients with Colorectal Cancer. Dis Colon Rectum (2008) 51(1):50-5. doi:10.1007/s10350-007-9073-7

16. Kang H, O'Connell JB, Maggard MA, Sack J, and Ko CY. A 10-year Outcomes Evaluation of Mucinous and Signet-Ring Cell Carcinoma of the colon and Rectum. Dis Colon Rectum (2005) 48(6):1161-8. doi:10.1007/s10350-0040932-1

17. Zhou JL, Zhao XY, Lin GL, Qiu HZ, Xiao Y, Wu B, et al. [Clinicopathological Characteristics, Diagnosis, and Treatment of 29 Cases of Signet Ring Cell Carcinoma of the Rectum and Sigmoid colon]. Zhonghua Zhong Liu Za Zhi (2020) 42(10):897-902. doi:10.3760/cma.j.cn112152-20200228-00142

18. Chang DT, Pai RK, Rybicki LA, Dimaio MA, Limaye M, Jayachandran P, et al. Clinicopathologic and Molecular Features of Sporadic Early-Onset Colorectal Adenocarcinoma: an Adenocarcinoma with Frequent Signet Ring Cell Differentiation, Rectal and Sigmoid Involvement, and Adverse Morphologic Features. Mod Pathol (2012) 25(8):1128-39. doi:10.1038/modpathol.2012.61

19. Chou C-L, Tseng C-J, and Shiue Y-L. The Impact of Young Age on the Prognosis for Colorectal Cancer: a Population-Based Study in Taiwan. Jpn J Clin Oncol (2017) 47(11):1010-8. doi:10.1093/jjco/hyx110

20. Korphaisarn K, Morris V, Davis JS, Overman MJ, Fogelman DR, Kee BK, et al. Signet Ring Cell Colorectal Cancer: Genomic Insights into a Rare Subpopulation of Colorectal Adenocarcinoma. Br J Cancer (2019) 121(6): 505-10. doi:10.1038/s41416-019-0548-9

21. Siegel RL, Miller KD, Goding Sauer A, Fedewa SA, Butterly LF, Anderson JC, et al. Colorectal Cancer Statistics, 2020. CA A Cancer J Clin (2020) 70(3): 145-64. doi:10.3322/caac.21601

22. Chen JS, Hsieh PS, Hung SY, Tang R, Tsai WS, Changchien CR, et al. Clinical Significance of Signet Ring Cell Rectal Carcinoma. Int J Colorectal Dis (2004) 19(2):102-7. doi:10.1007/s00384-003-0515-y

23. Shirouzu K, Isomoto H, Morodomi T, Ogata Y, Akagi Y, and Kakegawa T. Primary Linitis Plastica Carcinoma of the colon and Rectum. Cancer (1994) 74(7):1863-8. doi:10.1002/1097-0142(19941001)74:7<1863::aidcncr2820740706 $>3.0 . c 0 ; 2-3$

24. Psathakis D, Schiedeck THK, Krug F, Oevermann E, Kujath P, and Bruch H-P. Ordinary Colorectal Adenocarcinoma vs. Primary Colorectal Signet-Ring Cell Carcinoma. Dis Colon Rectum (1999) 42(12):1618-25. doi:10.1007/ BF02236218

25. Imperial R, Ahmed Z, Toor OM, Erdoğan C, Khaliq A, Case P, et al. Comparative Proteogenomic Analysis of Right-Sided colon Cancer, LeftSided colon Cancer and Rectal Cancer Reveals Distinct Mutational Profiles. Mol Cancer (2018) 17(1):177. doi:10.1186/s12943-018-0923-9

26. Distler P, and Holt PR. Are Right- and Left-Sided colon Neoplasms Distinct Tumors? Dig Dis (1997) 15(4-5):302-11. doi:10.1159/000171605

27. Sung CO, Seo JW, Kim K-M, Do I-G, Kim SW, and Park C-K. Clinical Significance of Signet-Ring Cells in Colorectal Mucinous Adenocarcinoma. Mod Pathol (2008) 21(12):1533-41. doi:10.1038/modpathol.2008.170

28. Kakar S, Deng G, Smyrk TC, Cun L, Sahai V, and Kim YS. Loss of Heterozygosity, Aberrant Methylation, BRAF Mutation and KRAS Mutation in Colorectal Signet Ring Cell Carcinoma. Mod Pathol (2012) 25(7):1040-7. doi:10.1038/modpathol.2012.44

29. Thota R, Fang X, and Subbiah S. Clinicopathological Features and Survival Outcomes of Primary Signet Ring Cell and Mucinous Adenocarcinoma of colon: Retrospective Analysis of VACCR Database. J Gastrointest Oncol (2014) 5(1):18-24. doi:10.3978/j.issn.2078-6891.2013.051

30. Yang L-l., Wang M, and He P. Clinicopathological Characteristics and Survival in Colorectal Signet Ring Cell Carcinoma: a Population-Based Study. Sci Rep (2020) 10(1):10460. doi:10.1038/s41598-020-67388-6

31. Siegel RL, Miller KD, Fuchs HE, and Jemal A. Cancer Statistics, 2021. CA A Cancer J Clin (2021) 71(1):7-33. doi:10.3322/caac.21654

32. Hugen N, van de Velde CJH, de Wilt JHW, and Nagtegaal ID. Metastatic Pattern in Colorectal Cancer Is Strongly Influenced by Histological Subtype. Ann Oncol (2014) 25(3):651-7. doi:10.1093/annonc/mdt591

33. Wu Y, Zhou J, Liu T, Xu L, and Xiao Y. Multiple Polypoid Colonic Metastases from Rectal Adenocarcinoma with Signet Ring Cells Features: a Case Report. BMC Gastroenterol (2020) 20(1):337. doi:10.1186/s12876-020-01493-8

34. Nagahisa Y, Kai C, Hattori K, Sakurai R, Matsuba Y, Hashida K, et al. [A Case of Signet-Ring Cell Carcinoma of the Sigmoid Colon with Disseminated Carcinomatosis Successfully Treated with CPT-11/Panitumumab]. Gan To Kagaku Ryoho (2015) 42(13):2477-9.

35. Börger M, Gosens M, Jeuken J, van Kempen L, van de Velde C, van Krieken J, et al. Signet Ring Cell Differentiation in Mucinous Colorectal Carcinoma. J Pathol (2007) 212(3):278-86. doi:10.1002/path.2181

36. Zhu L, Ling C, Xu T, Zhang J, Zhang Y, Liu Y, et al. Clinicopathological Features and Survival of Signet-Ring Cell Carcinoma and Mucinous Adenocarcinoma of Right Colon, Left Colon, and Rectum. Pathol Oncol Res (2021) 27. doi:10.3389/pore.2021.1609800

37. Benedix F, Kuester D, Meyer F, and Lippert H. Einfluss des muzinösen und siegelringzelligen Subtyps auf epidemiologische, histologische und molekularbiologische Eigenschaften sowie auf die Prognose des kolorektalen Karzinoms. Zentralbl Chir (2013) 138(4):427-33. doi:10.1055/ s-0031-1283870

38. Mizushima T, Nomura M, Fujii M, Akamatsu H, Mizuno H, Tominaga H, et al. Primary Colorectal Signet-Ring Cell Carcinoma: Clinicopathological Features and Postoperative Survival. Surg Today (2010) 40(3):234-8. doi:10.1007/ s00595-009-4057-y

39. Gopalan V, Smith RA, Ho Y-H, and Lam AK-Y. Signet-ring Cell Carcinoma of Colorectum-Current Perspectives and Molecular Biology. Int J Colorectal Dis (2011) 26(2):127-33. doi:10.1007/s00384-010-1037-Z

40. Verhulst J, Ferdinande L, Demetter P, and Ceelen W. Mucinous Subtype as Prognostic Factor in Colorectal Cancer: a Systematic Review and MetaAnalysis. J Clin Pathol (2012) 65(5):381-8. doi:10.1136/jclinpath-2011200340

41. Klaver YLB, Lemmens VEPP, Creemers GJ, Rutten HJT, Nienhuijs SW, and de Hingh IHJT. Population-based Survival of Patients with Peritoneal Carcinomatosis from Colorectal Origin in the Era of Increasing Use of Palliative Chemotherapy. Ann Oncol (2011) 22(10):2250-6. doi:10.1093/ annonc/mdq762

42. Fodde R, Smits R, and Clevers H. APC, Signal Transduction and Genetic Instability in Colorectal Cancer. Nat Rev Cancer (2001) 1(1):55-67. doi:10.1038/35094067

43. Comprehensive Molecular Characterization of Human colon and Rectal Cancer (2012). Nature 487 (7407):330-7. doi:10.1038/nature11252

44. Li Y, Li J, Wang R, Zhang L, Fu G, Wang X, et al. Frequent RNF43 Mutation Contributes to Moderate Activation of Wnt Signaling in Colorectal SignetRing Cell Carcinoma. Protein Cell (2020) 11(4):292-8. doi:10.1007/s13238020-00691-0

45. Nam J-Y, Oh BY, Hong HK, Bae JS, Kim TW, Ha SY, et al. Molecular Characterization of Colorectal Signet-Ring Cell Carcinoma Using WholeExome and RNA Sequencing. Translational Oncol (2018) 11(4):836-44. doi:10.1016/j.tranon.2018.04.007

46. Leggett B, and Whitehall V. Role of the Serrated Pathway in Colorectal Cancer Pathogenesis. Gastroenterology (2010) 138(6):2088-100. doi:10.1053/ j.gastro.2009.12.066

47. Wang R, Ma X, Li Y, He Y, Huang D, Cai S, et al. The Characteristics and Prognostic Effect of E-Cadherin Expression in Colorectal Signet Ring Cell Carcinoma. PLoS One (2016) 11(8):e0160527. doi:10.1371/ journal.pone. 0160527

48. Nusse R, and Clevers H. Wnt/ $\beta$-Catenin Signaling, Disease, and Emerging Therapeutic Modalities. Cell (2017) 169(6):985-99. doi:10.1016/ j.cell.2017.05.016 
49. Nanki K, Toshimitsu K, Takano A, Fujii M, Shimokawa M, Ohta Y, et al. Divergent Routes toward Wnt and R-Spondin Niche Independency during Human Gastric Carcinogenesis. Cell (2018) 174(4):856-69. doi:10.1016/j.cell.2018.07.027

50. Orsulic S, Huber O, Aberle H, Arnold S, and Kemler R. E-cadherin Binding Prevents Beta-Catenin Nuclear Localization and Beta-catenin/LEF-1Mediated Transactivation. J Cel Sci (1999) 112(Pt 8):1237-45. doi:10.1242/ jcs.112.8.1237

51. Gottardi CJ, Wong E, and Gumbiner BM. E-cadherin Suppresses Cellular Transformation by Inhibiting $\beta$-Catenin Signaling in an Adhesionindependent Manner. J Cel Biol (2001) 153(5):1049-60. doi:10.1083/ jcb.153.5.1049

52. Aitchison A, Hakkaart C, Whitehead M, Khan S, Siddique S, Ahmed R, et al. CDH1 Gene Mutation in Early-Onset, Colorectal Signet-Ring Cell Carcinoma. Pathol - Res Pract (2020) 216(5):152912. doi:10.1016/j.prp.2020.152912

53. Karapetis CS, Khambata-Ford S, Jonker DJ, O'Callaghan CJ, Tu D, Tebbutt NC, et al. K-rasMutations and Benefit from Cetuximab in Advanced Colorectal Cancer. N Engl J Med (2008) 359(17):1757-65. doi:10.1056/NEJMoa0804385

54. Pai RK, Jayachandran P, Koong AC, Chang DT, Kwok S, Ma L, et al. BRAFmutated, Microsatellite-Stable Adenocarcinoma of the Proximal Colon. Am J Surg Pathol (2012) 36(5):744-52. doi:10.1097/PAS.0b013e31824430d7

55. Li WQ, Kawakami K, Ruszkiewicz A, Bennett G, Moore J, and Iacopetta B. BRAF Mutations Are Associated with Distinctive Clinical, Pathological and Molecular Features of Colorectal Cancer Independently of Microsatellite Instability Status. Mol Cancer (2006) 5:2. doi:10.1186/1476-4598-5-2

56. Nagasaka T, Sasamoto H, Notohara K, Cullings HM, Takeda M, Kimura K, et al. Colorectal Cancer with Mutation in BRAF, KRAS, and Wild-type with Respect to Both Oncogenes Showing Different Patterns of DNA Methylation. Jco (2004) 22(22):4584-94. doi:10.1200/jco.2004.02.154

57. Fang M, Ou J, Hutchinson L, and Green MR. The BRAF Oncoprotein Functions through the Transcriptional Repressor MAFG to Mediate the CpG Island Methylator Phenotype. Mol Cell (2014) 55(6):904-15. doi:10.1016/j.molcel.2014.08.010

58. Wei Q, Wang X, Gao J, Li J, Li J, Qi C, et al. Clinicopathologic and Molecular Features of Colorectal Adenocarcinoma with Signet-Ring Cell Component. PLoS One (2016) 11(6):e0156659. doi:10.1371/journal.pone.0156659

59. Kim H, Kim B-H, Lee D, and Shin E. Genomic Alterations in Signet Ring and Mucinous Patterned Colorectal Carcinoma. Pathol - Res Pract (2019) 215(10): 152566. doi:10.1016/j.prp.2019.152566

60. Ogino S, Brahmandam M, Cantor M, Namgyal C, Kawasaki T, Kirkner G, et al. Distinct Molecular Features of Colorectal Carcinoma with Signet Ring Cell Component and Colorectal Carcinoma with Mucinous Component. Mod Pathol (2006) 19(1):59-68. doi:10.1038/modpathol.3800482

61. Inamura K, Yamauchi M, Nishihara R, Kim SA, Mima K, Sukawa Y, et al. Prognostic Significance and Molecular Features of Signet-Ring Cell and Mucinous Components in Colorectal Carcinoma. Ann Surg Oncol (2015) 22(4):1226-35. doi:10.1245/s10434-014-4159-7

62. Alvi MA, Loughrey MB, Dunne P, McQuaid S, Turkington R, Fuchs M-A, et al. Molecular Profiling of Signet Ring Cell Colorectal Cancer Provides a strong Rationale for Genomic Targeted and Immune Checkpoint Inhibitor Therapies. Br J Cancer (2017) 117(2):203-9. doi:10.1038/bjc.2017.168

63. Mei ZB, Duan CY, Li CB, Cui L, and Ogino S. Prognostic Role of Tumor PIK3CA Mutation in Colorectal Cancer: a Systematic Review and MetaAnalysis. Ann Oncol (2016) 27(10):1836-48. doi:10.1093/annonc/mdw264

64. Liao X, Lochhead P, Nishihara R, Morikawa T, Kuchiba A, Yamauchi M, et al. Aspirin Use, TumorPIK3CAMutation, and Colorectal-Cancer Survival. N Engl J Med (2012) 367(17):1596-606. doi:10.1056/NEJMoa1207756

65. Kim A, Lee J-E, Lee S-S, Kim C, Lee S-J, Jang W-S, et al. Coexistent Mutations ofKRASandPIK3CAaffect the Efficacy of NVP-Bez235, a Dual PI3K/MTOR Inhibitor, in Regulating the PI3K/MTOR Pathway in Colorectal Cancer. Int J Cancer (2013) 133(4):984-96. doi:10.1002/ijc.28073

66. Wasserman I, Lee LH, Ogino S, Marco MR, Wu C, Chen X, et al. SMAD4 Loss in Colorectal Cancer Patients Correlates with Recurrence, Loss of Immune Infiltrate, and Chemoresistance. Clin Cancer Res (2019) 25(6):1948-56. doi:10.1158/1078-0432.CCR-18-1726

67. Fleming NI, Jorissen RN, Mouradov D, Christie M, Sakthianandeswaren A, Palmieri M, et al. SMAD2, SMAD3 and SMAD4 Mutations in Colorectal Cancer. Cancer Res (2013) 73(2):725-35. doi:10.1158/0008-5472.Can-122706
68. Lamouille S, Xu J, and Derynck R. Molecular Mechanisms of EpithelialMesenchymal Transition. Nat Rev Mol Cell Biol (2014) 15(3):178-96. doi: $10.1038 / \mathrm{nrm} 3758$

69. Ziemke M, Patil T, Nolan K, Tippimanchai D, and Malkoski SP. Reduced Smad4 Expression and DNA Topoisomerase Inhibitor Chemosensitivity in Non-small Cell Lung Cancer. Lung Cancer (2017) 109:28-35. doi:10.1016/ j.lungcan.2017.04.017

70. Siraj AK, Pratheeshkumar P, Divya SP, Parvathareddy SK, Bu R, Masoodi T, et al. Tgfß-Induced SMAD4-dependent Apoptosis Proceeded by EMT in CRC. Mol Cancer Ther (2019) 18(7):1312-22. doi:10.1158/1535-7163.mct-18-1378

71. Marzouk O, and Schofield J. Review of Histopathological and Molecular Prognostic Features in Colorectal Cancer. Cancers (2011) 3(2):2767-810. doi:10.3390/cancers3022767

72. Boland CR, and Goel A. Microsatellite Instability in Colorectal Cancer. $\begin{array}{llll}\text { Gastroenterology (2010) 138(6):2073-87. doi:10.1053/ } & \end{array}$ j.gastro.2009.12.064e2073

73. Sinicrope FA. Lynch Syndrome-Associated Colorectal Cancer. N Engl J Med (2018) 379(8):764-73. doi:10.1056/NEJMcp1714533

74. Ogino S, Nosho K, Kirkner GJ, Kawasaki T, Meyerhardt JA, Loda M, et al. CpG Island Methylator Phenotype, Microsatellite Instability, BRAF Mutation and Clinical Outcome in colon Cancer. Gut (2009) 58(1):90-6. doi:10.1136/ gut.2008.155473

75. Kakar S, and Smyrk TC. Signet Ring Cell Carcinoma of the Colorectum: Correlations between Microsatellite Instability, Clinicopathologic Features and Survival. Mod Pathol (2005) 18(2):244-9. doi:10.1038/modpathol.3800298

76. Hartman DJ, Nikiforova MN, Chang DT, Chu E, Bahary N, Brand RE, et al. Signet Ring Cell Colorectal Carcinoma. Am J Surg Pathol (2013) 37(7):969-77. doi:10.1097/PAS.0b013e3182851e2b

77. Yalcin S, and Onguru O. BRAF Mutation in Colorectal Carcinomas with Signet Ring Cell Component. Cancer Biol Med (2017) 14(3):287-92. doi:10.20892/ j.issn.2095-3941.2017.0053

78. Tajiri K, Sudou T, Fujita F, Hisaka T, Kinugasa T, and Akagi Y. Clinicopathological and Corresponding Genetic Features of Colorectal Signet Ring Cell Carcinoma. Anticancer Res (2017) 37(7):3817-23. doi:10.21873/anticanres.11760

79. Bruni D, Angell HK, and Galon J. The Immune Contexture and Immunoscore in Cancer Prognosis and Therapeutic Efficacy. Nat Rev Cancer (2020) 20(11): 662-80. doi:10.1038/s41568-020-0285-7

80. Galon J, and Bruni D. Tumor Immunology and Tumor Evolution: Intertwined Histories. Immunity (2020) 52(1):55-81. doi:10.1016/j.immuni.2019.12.018

81. Kishore C, and Bhadra P. Current Advancements and Future Perspectives of Immunotherapy in Colorectal Cancer Research. Eur J Pharmacol (2021) 893: 173819. doi:10.1016/j.ejphar.2020.173819

82. Ishihara S, Watanabe T, Akahane T, Shimada R, Horiuchi A, Shibuya H, et al. Tumor Location Is a Prognostic Factor in Poorly Differentiated Adenocarcinoma, Mucinous Adenocarcinoma, and Signet-Ring Cell Carcinoma of the colon. Int J Colorectal Dis (2012) 27(3):371-9. doi:10.1007/s00384-011-1343-0

83. Lee W-S, Chun H-K, Lee WY, Yun SH, Cho YB, Yun H-R, et al. Treatment Outcomes in Patients with Signet Ring Cell Carcinoma of the Colorectum. Am J Surg (2007) 194(3):294-8. doi:10.1016/j.amjsurg.2006.12.041

84. Zhao Z, Yan N, Pan S, Wang D-w., and Li Z-w. The Value of Adjuvant Chemotherapy in Stage II/III Colorectal Signet Ring Cell Carcinoma. Sci Rep (2020) 10(1):14126. doi:10.1038/s41598-020-70985-0

85. Prabhu A, Brandl A, Wakama S, Sako S, Ishibashi H, Mizumoto A, et al. Retrospective Analysis of Patients with Signet Ring Subtype of Colorectal Cancer with Peritoneal Metastasis Treated with CRS \& HIPEC. Cancers (2020) 12(9):2536. doi:10.3390/cancers 12092536

86. Winer J, Zenati M, Ramalingam L, Jones H, Zureikat A, Holtzman M, et al. Impact of Aggressive Histology and Location of Primary Tumor on the Efficacy of Surgical Therapy for Peritoneal Carcinomatosis of Colorectal Origin. Ann Surg Oncol (2013) 21(5):1456-62. doi:10.1245/s10434-0133328-4

87. Narasimhan V, Tan S, Kong J, Pham T, Michael M, Ramsay R, et al. Prognostic Factors Influencing Survival in Patients Undergoing Cytoreductive Surgery with Hyperthermic Intraperitoneal Chemotherapy for Isolated Colorectal Peritoneal Metastases: a Systematic Review and Meta-analysis. Colorectal Dis (2020) 22(11):1482-95. doi:10.1111/codi.15003 
88. Zhou J, Wang C, Lin G, Xiao Y, Jia W, Xiao G, et al. Serial Circulating Tumor DNA in Predicting and Monitoring the Effect of Neoadjuvant Chemoradiotherapy in Patients with Rectal Cancer: A Prospective Multicenter Study. Clin Cancer Res (2021) 27(1):301-10. doi:10.1158/10780432.CCR-20-2299

89. Zhang J, Zheng J, Yang Y, Lu J, Gao J, Lu T, et al. Molecular Spectrum of KRAS, NRAS, BRAF and PIK3CA Mutations in Chinese Colorectal Cancer Patients: Analysis of 1,110 Cases. Sci Rep (2015) 5:18678. doi:10.1038/ srep 18678

90. Chew M-H, Yeo S-AE, Ng Z-P, Lim K-H, Koh P-K, Ng K-H, et al. Critical Analysis of Mucin and Signet Ring Cell as Prognostic Factors in an Asian Population of 2,764 Sporadic Colorectal Cancers. Int J Colorectal Dis (2010) 25(10):1221-9. doi:10.1007/s00384-010-1033-3

91. Liang Z, Yan D, Li G, and Cheng H. Clinical Analysis of Primary Colorectal Signet-Ring Cell Carcinoma. Clin Colorectal Cancer (2018) 17(1):e39-e44. doi:10.1016/j.clcc.2017.06.010
92. Kawabata Y, Tomita N, Monden T, Ohue M, Ohnishi T, Sasaki M, et al. Molecular Characteristics of Poorly Differentiated Adenocarcinoma and Signet-Ring-Cell Carcinoma of Colorectum. Int J Cancer (1999) 84(1):33-8. doi:10.1002/(sici)1097-0215(19990219)84:1<33::aid-ijc7>3.0.co;2-Z

93. Chen J, Zhou L, Gao J, Lu T, Wang J, Wu H, et al. Clinicopathological Characteristics and Mutation Spectrum of Colorectal Adenocarcinoma with Mucinous Component in a Chinese Cohort: Comparison with Classical Adenocarcinoma. Front Oncol (2020) 10:917. doi:10.3389/fonc.2020.00917

Copyright (c) 2021 An, Zhou, Lin, Wu, Cong, Li, Qiu and Shi. This is an open-access article distributed under the terms of the Creative Commons Attribution License (CC $B Y)$. The use, distribution or reproduction in other forums is permitted, provided the original author(s) and the copyright owner(s) are credited and that the original publication in this journal is cited, in accordance with accepted academic practice. No use, distribution or reproduction is permitted which does not comply with these terms. 